\title{
RASTROS DO CisNe PRETO: LINO GUEDES, UM ESCRITOR NEGRO PELOS JORNAIS (1913-1969)
}

Traces of the Black Swan: Lino Guedes, a black writer on the newspapers (1913-1969)

Los rastros del Cisne Negro: Lino Guedes, un escritor negro por los periódicos (1913-1969)

\author{
MÁrio Augusto Medeiros dA Silva
}

http://dx.doi.org/10.1590/S2178-14942017000300005

Mário Augusto Medeiros da Silva é mestre e doutor em Sociologia pela Universidade Estadual de Campinas (UNICAMP) e professor do Departamento de Sociologia da mesma instituição. Este artigo recebeu apoio da Fundação Biblioteca Nacional por meio do Edital de Apoio a Pesquisadores Negros (mariomed@unicamp.br).

Artigo recebido em 1 de junho e aprovado para publicação em 30 de agosto de 2017. 


\title{
RESUMO
}

Discuto, neste artigo, aspectos da trajetória de ativismo intelectual e literário do escritor negro paulista Lino Guedes. Baseado em fontes de jornais e no mapeamento inicial de sua produção literária, busco entender como o autor figurou no debate público sobre o negro em São Paulo no pós-Abolição. Dada a pouca produção analítica específica sobre Guedes e o desconhecimento das condições sociais e intelectuais em que ele se fez possível, a pesquisa tentou reconstruir contextos sociais e intelectuais em que ele se inseriu. Espera-se contribuir para o debate sobre o protagonismo de intelectuais negros na cena pública no início do século XX em São Paulo.

Palavras-Chave: Lino Guedes; pós-Abolição; intelectuais negros; escritores negros brasileiros; ativismo político negro.

\begin{abstract}
In this article, I discuss aspects of the intellectual and literary activism of a black writer called Lino Guedes, born in the state of São Paulo. Based on sources from newspapers and on the initial mapping of his literary production, I try to explain how this author has figured in the public debate about black people in São Paulo in the post-Abolition period. In view of the limited analytical production about Lino Guedes as well as the lack of information about the social and intellectual conditions that made his work possible, this research tries to reconstruct the social and intellectual contexts in which he was inserted. I hope to contribute to the debate on the role played by black intellectuals in the public life in the early twentieth century in São Paulo.
\end{abstract}

KEYwords: Lino Guedes; post-Abolition; black intellectuals; Brazilian black writers; black political activism

\section{RESUMEN}

En este artículo busco discutir los aspectos de la trayectoria del activismo intelectual y literario de un escritor negro llamado Lino Guedes, nacido en el estado de São Paulo. Con base en fuentes de periódicos y en la cartografía inicial de su producción literaria, trato de explicar la manera en que este autor ha figurado en el debate público sobre los negros tras la abolición de la esclavitud en São Paulo. Sin embargo, es necesario reconocer la escasa producción analítica sobre Lino Guedes, así como la falta de conocimiento sobre las condiciones sociales e intelectuales que hicieron posible su trabajo. Esta investigación es, pues, un intento de reconstruir los contextos sociales e intelectuales en los que estuvo inmerso Guedes. Espero poder contribuir al debate acerca del protagonismo de los intelectuales negros en la vida pública de principios del siglo XX en São Paulo.

Palabras Clave: Lino Guedes; intelectuales negros; escritores negros brasileños; activismo político negro. 


\section{INTRODUÇÃO}

uase tudo o que é sabido sobre Lino Pinto Guedes (1896-1951) tateia as relações entre
o contexto e as condições sociais da produção de sua obra. A data de seu aniversário é alvo de disputas; ${ }^{1}$ há poucos dados sobre sua vida familiar em Socorro (SP), como descendente de escravizados, ou sobre seus trajetos pelo interior paulista até chegar à capital. Por quê?

A) Seus livros, encontrados em sebos, custam centenas de reais;:² B) A divulgação das obras foi feita por uma militância cultural negra paulistana, a exemplo de Correia Leite (Cuti e Leite, 1992), Colina (1982), Quilombhoje (1985) ou Camargo (1986, 1987, 2016), que 0 inseriu em antologias e estudos de literatura negra brasileira. Houve interesse de poucos pesquisadores pelo autor e suas ações, como foi o caso de Bastide (1973), Brookshaw (1983) e Bernd (1987), Duarte (2011), Gomes (2011: 349-363), Miranda (2005), Domingues (2010) e Gonçalves (2012). Acrescente-se que: C) Parentes ou descendentes são falecidos, como sua fiIha Hendi Guedes Queiroz; ${ }^{3}$ D) Seus livros podem ser encontrados em bibliotecas públicas, mas são preservados como obras raras na Biblioteca Nacional, na Coleção Mário de Andrade do Instituto de Estudos Brasileiros da USP e na Biblioteca Municipal Mário de Andrade. Por fim: E) Pesquisadores que foram seus contemporâneos ou de seus descendentes não produziram, salvo engano, entrevistas com o autor.

\footnotetext{
1 “Para Oswaldo de Camargo (1987), o autor nasceu em 24/06/1897. Já para Raimundo de Menezes (1969), Zilá Bernd (1992), Eduardo de Oliveira (1998) e Afrânio Coutinho (2001), Guedes teria nascido em 23/07/1906, informação confirmada pelo catálogo da Biblioteca Mário de Andrade." Cf. http://www.letras.ufmg.br/literafro/, acesso em 28/03/2017. Domingues (2010) confirmou a data de nascimento indicada por Camargo. Porém mesmo esta é disputável, como se verá. ${ }^{2}$ Negro preto cor da noite esteve anunciado no Mercado Livre por $\mathrm{R} \$ 22.500,00$. 0 preço caiu para $\mathrm{R} \$ 5$ mil (acesso em 02/05/2017). O pequeno bandeirante, no mesmo período, esteve disponível por $\mathrm{R} \$ 500,00$ na Estante Virtual (acesso em 23/02/2015). Já no Mercado Livre, o mesmo livro esteve até recentemente anunciado por $R \$ 200,00$ (acesso em 02/05/2017).

3 "Hendi Guedes Queiroz - Aos 68 anos. Filha do sr. Lino Guedes e d. Felícia Assis Guedes, era viúva do sr. Lourival Pereira de Queiroz. Deixa filhos. 0 enterro realizou-se no Cemitério São Paulo". Ver: Falecimentos. O Estado de São Paulo, São Paulo, 06 de julho de 2003, p. C7. Descobri sua neta, Demarise Queiroz, em 2014, através de informações de internet e perfil numa rede social. Após Ihe escrever, recebi a resposta de seu irmão, J. R. Queiroz, informando-me que Demarise falecera em março de 2013. Não conseguimos mais nos falar. Mas sou grato a ele, a Oswaldo de Camargo e a Marciano Ventura pelas informações recebidas.
} 
Trata-se de um autor negro militante que entre os anos 1920 e 1950 publicou livros autoeditados em gráficas e tipografias, trazendo ao público uma poesia em que os negros, no passado e no presente, e seus modos de vida são os personagens centrais, e narrando uma história coletiva desse grupo. Guedes foi também um dos fundadores de um jornal voltado para os "homens de cor" no interior de São Paulo, O Getulino. E após 40 anos da Abolição da escravatura já era revisor em periódicos importantes da capital, mas também mencionado em notas de jornais como poeta preto, poeta da raça negra.

Discuto aspectos desse percurso com base em fontes encontradas na imprensa periódica paulista. E, com isto, avento que Guedes e sua trajetória (e as lacunas sobre ela) são indícios do quanto se desconhece sobre o protagonismo de intelectuais e escritores negros brasileiros no começo do século XX em São Paulo, afrontando os alcances e limites da liberdade.

\section{ESBOÇOS DE FIGURA}
T eia-se no Suplemento Literário do jornal O Estado de São Paulo um texto de memórias sobre a cidade e o trabalho nas redações:

Por volta de 1934 o Viaduto do Chá [...] ao lado da Praça do Patriarca, [...] encontrava-se a redação do "Diário de São Paulo". [...]

A revisão do "Diário" funcionava praticamente dentro da tipografia, num canto cheio de mesas tôscas, cobertas com folhas de bobinas, onde se trabalhava em ambiente desprovido dos mais elementares requisitos de conforto ou higiene. Respirava-se poeira e antimônio. Tudo era difícil primário e improvisado. [...] o pessoal da revisão sofria, suportando o cheiro forte do chumbo e da tinta [...] o martelamento constante do aparelho auditivo pelas fresadoras e máquinas de serra, sem falar na deficiência de luz [...]

O chefe de revisão do "Diário de São Paulo", Lino Guedes, estava longe de ser um desses homens que despertam simpatia à primeira vista. Negro de lábios grossos, nariz achatado e feições características da raça, pouco expansivo, gestos nervosos, falando apenas o essencial e raramente fixando o interlocutor, não inspirava confiança.

Disso já me prevenira José de Moraes Andrade [...] [que] trabalhava por esse tempo como "cozinheiro" - precursor do "copy-desk" [...] e fôra o meu padrinho junto a Lino Guedes para a obtenção do precário "bico" [...] Vendo-o, ninguém poderia suspeitar de que naquela figura aparentemente ríspida e vulgar se escondia um poeta delicado, que cantava a tristeza do homem 
de côr e lamentava a sorte das criancinhas negras. Não tinha certamente as dimensões de um Cruz e Sousa, mas seria tão carregado de amargores como o seu genial irmão do Destêrro [...] Contrariando seu temperamento sombrio, procurava ser gentil e acabou convidando-me para almoçar um domigo em sua casa, na Rua Batatais, ocasião em que me ofereceu um livrinho de versos com amavel dedicatória. Tive oportunidade, então, de observar a enorme sensibilidade humana de Lino Guedes, compreendendo a alma que se debatia naquele arcabouço físico tão desajeitado. [...] Passou-se o tempo, Lino Guedes morreu [...] Ele foi um poeta. Um poeta negro. $^{4}$

As condições do ambiente de trabalho num jornal como o Diário de São Paulo estão atreladas à hierarquia organizacional, onde a revisão ocupa um estrato baixo. Esse patamar se torna, na história da imprensa brasileira, a porta de entrada de sujeitos talvez sem padrinhos ou oriundos de classes e grupos sociais desprestigiados, como os negros, que antes trilhavam o caminho da tipografia, como fizeram Francisco de Paula Brito e Machado de Assis, entre outros. Da descrição emerge a figura antipática, entalhada pelas "características da raça", "ríspida e vulgar", "que não inspiraria confiança". Mudemos a perspectiva: o chefe negro abrutalhado, física e emocionalmente, em meio a condições insalubres, que deveria, então, acomodar um aspirante branco naquele lugar.

Com preconceito, as recordações situam Guedes num jornal paulistano de importância; descrevem-no; localizam sua moradia na capital; qualificam-no como poeta negro. 0 texto registra uma recordação de Guedes 46 anos depois da Abolição da escravidão, quando teria algo em torno de 38 anos. No entanto, no documento expedido em 28 de dezembro de 1950, onde Lino Guedes pede sua aposentadoria por invalidez, pouco antes de falecer, fixa-se uma nova data de nascimento: 27 de junho de 1896.

Um intelectual negro na capital paulista vindo da zona cafeeira do estado, a cidade de Socorro. Filho dos ex-escravizados, talvez libertos antes de 1888, José Pinto Guedes e Benedita Eugênia Guedes, órfão de pai aos dois meses e com uma única irmã, Gracinda Guedes. De acordo com Domingues (2010), sua família foi protegida pelo chefe político local - e antigo senhor de escravos em Socorro -, o coronel Olympio Gonçalves dos Reis (Siqueira, 2005).

\footnotetext{
${ }^{4}$ Cunha Motta, "São Paulo de outros tempos", Suplemento Literário, O Estado de São Paulo, São Paulo, 31 de maio de 1969 , p. 4, colchetes e grifos meus.
} 


\section{Imagem 1: Documento de aposentadoria de Lino Pinto Guedes, expedido em 1950, com data de nascimento.}

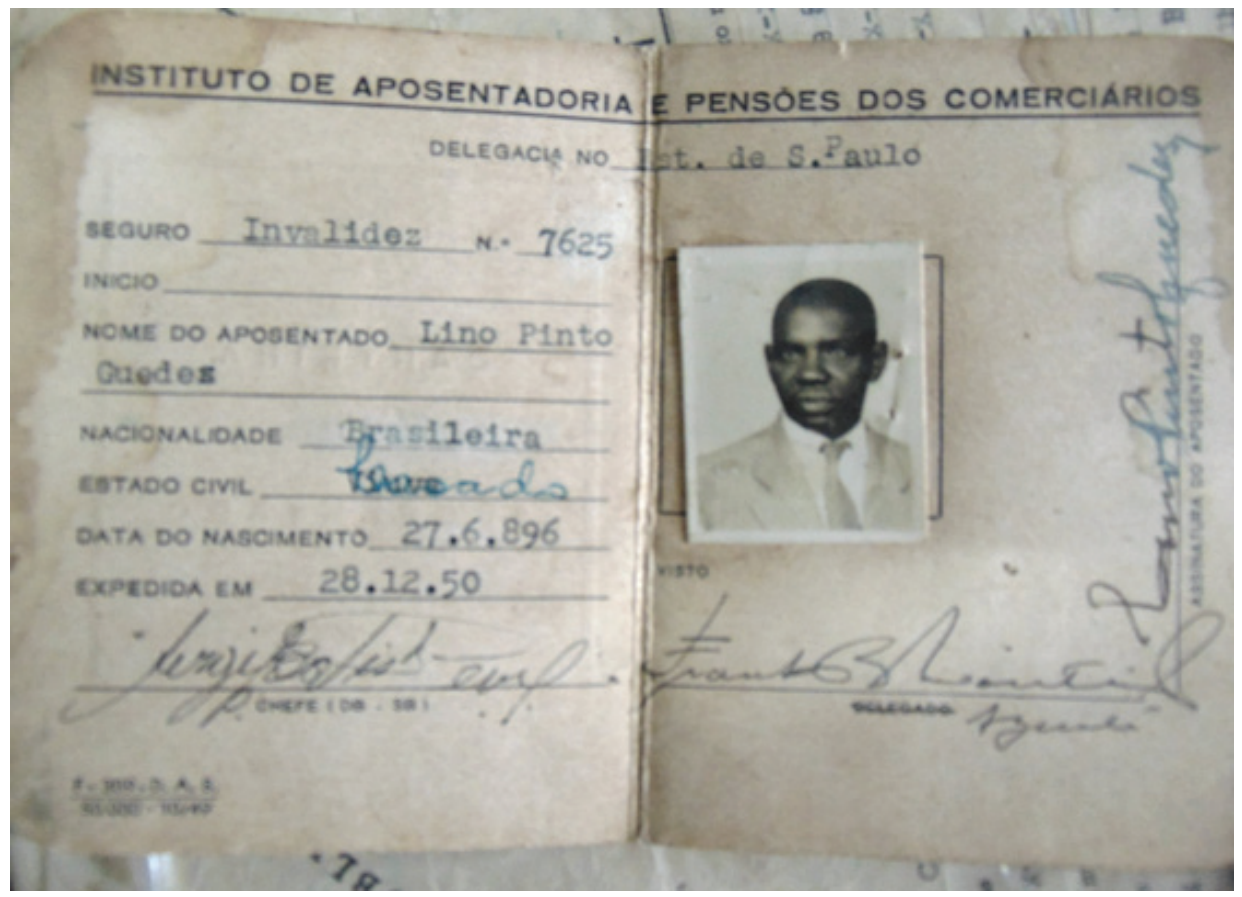

Fonte: Acervo familiar de J. R. Queiroz Guedes. Cessão: Marciano Ventura.

\section{UM NEGRO, FILHO DE NINGUÉM}

S upor proteção ajuda a pensar alguns dados iniciais da vida de Guedes. Flagrá-lo viajando, renses que faziam o percurso: "Em goso [sic] de férias, acham-se nesta cidade os estudantes Brasilino de Lima Junior, Jospe da Costa Antonio Mangolli, Felicio Vita Junior, Raphael de Salles Pulino, Aristides Pulino, Adelino Carvalho Junior, Lino Guedes e José Santoro."

Ao reportar a presença de socorrenses na cidade de São Paulo, o jornal menciona os nomes dos mesmos e de seus pais. Guedes é sempre colocado em último ou penúltimo lugar, e não é fornecida a identidade dos pais:

\footnotetext{
${ }^{5}$ Socorro. Correio Paulistano, São Paulo, 27 de dezembro de 1913, p. 9.
} 
[...] estiveram nesta cidade, em visita a suas famílias, os estudantes srs. Wenceslau Guimarães, filho da exma. Sra. d. Clotilde Guimarães; Antonio e Benedicto de Campos, filhos do sr. capitão Miguel de Campos, advogado do nosso fôro; José da Costa, filho do sr. capitão Manuel da Costa; Lino Guedes, e Aristides Pulino, filho do sr. major Francisco Antonio Pulino. ${ }^{6}$

- Acham-se nesta cidade:

[...] os jovens estudantes Antonio de Campos e Benedicto de Campos, filhos do capitão Miguel de Campos, advogado do nosso fôro; Mauro e Lincoln Camargo, filhos do sr. Major Gersemino Camargo; José e Luiz da Costa, filhos do sr. capitão Manuel da Costa; Antonio Vita, filho do sr. Vicente Vita; Adelino Carvalho, filho da exma. Sra. d. Sophia Carvalho. Guido d'Anna, filho do sr. Vicente D’Anna e Lino Guedes. ${ }^{7}$

A ausência de menção aos nomes dos pais de Guedes é tão significativa quanto a presença do seu nome próprio entre os dos filhos de uma camada social que se queria distinguir, por telegramas enviados ao tradicional jornal da capital. Fortalece-se o argumento do apadrinhamento protetivo de Guedes. Isso foi suficientemente robusto para que ele, enquanto jovem estudante, pudesse figurar nessas listas, não em patamar de igualdade, está claro.

O suposto apadrinhamento por um senhor de terras local não implicaria ausência de consciência de questões relativas ao seu grupo social. Sabe-se que o coronel Reis foi o responsável por custear seus estudos (Domingues, 2010), enviando-o para Campinas, para que pudesse frequentar a Escola Normal no município com o segundo maior número de escravizados do estado de São Paulo, o que legou uma população negra volumosa na região. Campinas também foi um centro significativo de associações negras, tanto recreativas como reivindicativas, contemporâneas ao momento em que Guedes chegou à cidade (Maciel, 1987). Assim, juntando-se os dados, torna-se compreensível a informação que encontrei publicada na seção "Notícias do Interior":

Entre os homens de côr - CAMPINAS, 11 - As diversas sociedades compostas de homens de côr, desta cidade, vão editar em brochura os discursos e conferencias do sr. Lino Guedes, feitos em S. Paulo e aqui com o intuito de aproximar cada vez mais as relações de amizade entre os homens de côr paulistanos e campineiros.

Esses trabalhos, coordenados, receberão o título de "Esboços". ${ }^{8}$

\footnotetext{
${ }^{6}$ Socorro. Correio Paulistano, São Paulo, 14 de abril de 1914, p. 4. Grifos meus.

${ }^{7}$ Socorro. Correio Paulistano, São Paulo, 18 de junho de 1915, p. 4. Grifos meus.

${ }^{8}$ O Estado de São Paulo, Notícias do Interior, 12 de setembro de 1919, p. 2.
} 
Em 1919, por volta dos 23 anos, Guedes se encontrava em Campinas e era reconhecido como alguém para falar em nome de ou para os negros da cidade. Figurava como uma ponte entre associações negras paulistanas e campineiras. Infelizmente os nomes das sociedades não foram publicados. Esse papel relativiza o peso do apadrinhamento de um antigo senhor de escravos de Socorro? Teria Guedes rompido com os sentidos que aquela proteção poderia conferir? Isso complexifica-se ao passo que o autor ocupa algum lugar, discursando, no espaço público reservado às expressões negras. ${ }^{9}$

Além de sua presença entre associações negras campineiras é possível ter indícios de Guedes entre jornais daquela cidade, não negros, ${ }^{10}$ em pêndulo entre dois mundos, de brancos e negros, o que se revela, por exemplo, por sua presença nos funerais do coronel Olympio Gonçalves dos Reis, cuja morte ocupa uma longa coluna em jornal. Ao final da lista, encontra-se em penúltimo lugar o nome de Lino Guedes. ${ }^{11} \mathrm{Ou}$, quando ainda era comemorado o Treze de Maio como feriado cívico, era comum que associações negras paulistas utilizassem a data para realizar atos, provas de atletismo, romarias aos túmulos de abolicionistas. Assim como a oração de intelectuais negros, constituindo-se num ponto de comunhão e reflexão:

[...] Campinas, 13 - [...] Em sua sede oficial o "Centro 13 de Maio" realizou uma sessão commemorativa da Lei Aurea [...] o "Gremio Dramatico Luiz Gama" effectuou um espetaculo de gala, em regosijo à data 13 de maio. [...] A Associação Protectora dos Brasileiros Pretos também organizou em sua sede social um grande festival [...] foi hoje distribuído um número especial do jornal "A Protectora" sob a direcção dos srs. Gonçalo Guedes e Lino Guedes. ${ }^{12}$

\section{TREZE DE MAIO}

s comemorações do 13 de maio abriam espaços para celebrações dos jornais pau-
listas e representantes das camadas dominantes, para a exortação de abolicionistas e a celebração do gesto de Isabel, a Redemptora. Do ângulo negro, a leitura do processo podia ser outra, atestando um progressivo recrudescimento da consciência da exploração e abandono, bem como uma crítica do processo abolicionista e republicano, resultando numa

\footnotetext{
${ }^{9} \mathrm{O}$ Bispo d. João Nery - Comemoração das Sociedades dos homens de cor. Correio Paulistano, Em Campinas, 22 de março de 1920, p. 1.

${ }^{10}$ Encontro de trens. Correio Paulistano, 17 de julho de 1920, p. 4.

${ }^{11}$ Notícias do interior - Socorro. Correio Paulistano, 23 de outubro de 1925, p. 7.

${ }^{12}$ Treze de Maio - as commemorações de hontem. Correio Paulistano, 14 de maio de 1922, p. 4.
} 
marginalização do negro como cidadão (Bastide, 1973; Ferrara, 1986; Pinto, 2010). Neste cenário encontra-se uma possibilidade interessante de mapear a presença de Lino Guedes e sua ambiência:

\section{"0 Getulino"}

Commemorando a data de hoje, appareceu o primeiro numero deste jornal que se editava em Campinas e passa agora a ser publicado aqui.

Sob a direcção de Lino Guedes, de Agnello Rodrigues e Gervasio de Moraes, dedica-se a nova publicação à defesa dos homens pretos do Brasil. 0 primeiro numero já é de esperanças e vigor, interessante e bem collaborado. Parabéns ${ }^{13}$

Algo semelhante se dá com a nota do primeiro livro de Guedes, no ano seguinte, também por ocasião do 13 de maio.

\section{Livros Novos}

\section{“O CANTO DO CYSNE PRETO" - de Lino Guedes - Typ. Aurea - São Paulo, 1927.}

O sr. Lino Guedes reuniu, em pequeno e elegante volume, as suas composições poeticas que, no dizer do respectivo prefaciador, são "um ensaio de literatura negra". Não há quem resista à vontade de transcrever um trecho do prefácio, que é encantador: "uma tristeza ingenita, colossal, provinda das solidões africanas e, subito, entre os labios grossos e carnudos, um sorriso a descobrir as fileiras sadias dos dentes aperolados: eis o "Canto do Cysne preto". [...] $]^{14}$

No transcorrer de um ano, há notícia de um jornal em homenagem a Luiz Gama - cujo nome literário era Getulino - durante as comemorações da Abolição. Outros dois fatos: menção à ideia de literatura negra, já em 1927, associada diretamente a uma obra de um autor negro brasileiro, no ano seguinte. Tendo Guedes como elemento unificador deles.

"Laly", a alcunha literária de Guedes, é de origem desconhecida. O canto do cisne preto inaugura suas publicações com capas que marcam uma ideia de experiência negra. 0 livro é prefaciado pelo jornalista Judas Isgorogota, atuante no Jornal do Commercio, onde Guedes também trabalhava como revisor. 0 canto do cisne remete a uma expressão dúbia: a crença antiga de que a ave branca era um pássaro que não podia emitir sons como outras, fazendo-o somente ao morrer, em ato final, sendo sinônimo de "última grande obra" de um artista. Guedes muda a perspectiva: o cisne em questão é preto e não se encontra à beira da morte,

\footnotetext{
${ }^{13}$ Treze de Maio! - a desgraça findou de toda uma raça... Folha da Manhã, 13 de maio de 1926, p. 1.

${ }^{14}$ Livros Novos. Correio Paulistano, 13 de maio de 1927, p. 4.
} 
mas em estreia, aos 31 anos. 0 livro é dividido em duas partes: "Dictinha", versos afetivos para uma personagem negra; e "Cortiço", cenas da vida negra nesse tipo de habitação.Versos simples, com forte cunho moral para a vida negra, como estes, do poema "Remédio único": "Unicamente, Dictinha/ Por sermos pretos, que horror/ Muita gente com malícia/ Vê nosso sincero amor/[...] / Mas com o nosso casamento/ Fartar-se-á a exigente/ Sociedade, Dictinha/ Salvemos pois nossa gente!/ Dando a ella o que já Ihe sobra, / Que é um nome bem decente!" (Guedes, 1927: 23). ${ }^{15}$

Imagem 2: $O$ canto do cysne preto, 1927.

Typographia Aurea. Capa: Sem indicação.
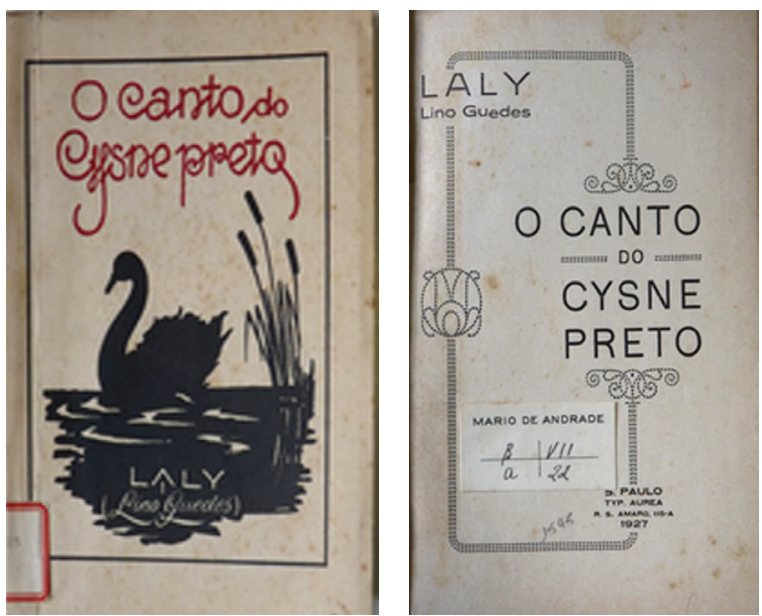

Coleção Mário de Andrade. IEB-USP.

Nas menções seguintes, no Correio Paulistano, sabe-se da existência da obra Black, livro de poemas do autor que teria sido doado ao Grêmio Literário Fagundes Varella (em 9 de maio de 1929), bem como da participação de Guedes em outro jornal da imprensa negra, o Progresso, codirigido pelo ativista negro Argentino Celso Wanderley (3 de julho de 1929).

Ao longo de 1930 ele organiza, junto com outros ativistas negros, tentativas de comemoração do centenário de Luiz Gama no movimento para erguer em praça pública uma herma em prol do Abolicionista Negro - o que aconteceria em 1931.

\footnotetext{
${ }^{15} \mathrm{O}$ lançamento de 0 canto do cysne preto também aparecerá em jornais negros como Clarim d'Alvorada (São Paulo, 13 de maio de 1927) e O Patrocínio (Piracicaba, 7 de setembro de 1928, n. 31).
} 
Às 8 horas celebrou-se com o ritual de costume, missa solenne na igreja do Rosario, assistindo os representantes das sociedades e órgãos da grande raça negra e innumeros admiradores do illustre abolicionista.

0 "Clarim da Alvorada" dedicou quasi todo o nummero de hontem ao culto de sua memória [...] Hoje, no cinema Odeon, num dos intervallos das sessões nocturnas, o sr. Lino Guedes, secretario da Comissão Organizadora das Homenagens, fará uma palestra sob o título: "Escravo e libertador"..[... $]^{16}$

0 pertencimento de Lino Guedes à comissão organizadora dos festejos pelo centenário de Gama não se deu de maneira isolada (Cuti e Leite, 1992: 77-90). Outros participantes também eram membros do jornal negro Progresso e anunciam o projeto da herma no Largo do Arouche, que seria alvo de seus esforços pelos meses seguintes:

[...] Graças à iniciativa do jornal "O Progresso", não será esquecida em São Paulo a grata epheméride. [...] organizou-se uma comissão constituída dos seguintes senhores: Argentino Celso Wanderley, Alipio Antonio da Silva, Benedicto Henrique Dias, Euclydes S. dos Santos, Frederico Baptista de Souza, Raul de Moraes e Lino Guedes. Esses cavalheiros que se propuzeram a erigir no largo do Arouche um bronze ao mestiço que morrera pela Abolição, obtiveram da Camara Paulista por um projeto de lei do dr. Synesio da Rocha a quantia de 5:000\$000.17

0 projeto da herma pelo grupo de Progresso já era algo anunciado desde o ano anterior, em 21 de junho de 1929. ${ }^{18}$ É interessante notar, assim, a colaboração ofertada por Guedes:

\section{Foi posto à venda o novo livro de Lino Guedes}

A ninguém deve ter passado despercebida a campanha que ora se faz, em S. Paulo, para erigir uma herma a Luiz Gama. 0 movimento que é todo chefiado pela raça negra [...] 0 trabalho de esculptura está prompto, mas a quantia ainda não foi coberta.

\footnotetext{
${ }^{16} \mathrm{Cf}$. Luiz Gama - as commemorações do primeiro centenário do inolvidável abolicionista. Folha da Manhã, 22 de junho de 1930, p. 3.0 nome do poeta é, em verdade, Luiz Gonzaga Pinto da Gama.

${ }^{17} 0$ primeiro centenário do nascimento de Luiz Gama. Folha da Manhã, 20 de junho de 1930, p. 2. Sobre Argentino Wanderley, ver Cuti e Leite (1992) e Von Simson (2007). A respeito de Frederico de Sousa, ver Ferrara (1986). No mesmo período, a campanha pela herma de Luiz Gama foi noticiada por A Gazeta e Diário Nacional.

${ }^{18}$ Centenário do nascimento de Luiz Gama. Folha da Noite, 11 de outubro de 1929, p. 2.
} 
Lino Guedes, conhecido mais pelo seu livro de versos, "O Canto do Cysne Preto", acaba de publicar nova obra - Ressurreição Negra - que está à venda em benefício do monumento de Luiz Gama. São artigos de estudos sociaes, visando sempre as necessidades da raça preta. [.....$^{19}$

Imagem 3: Ressurreição Negra, 1929. S/ed.

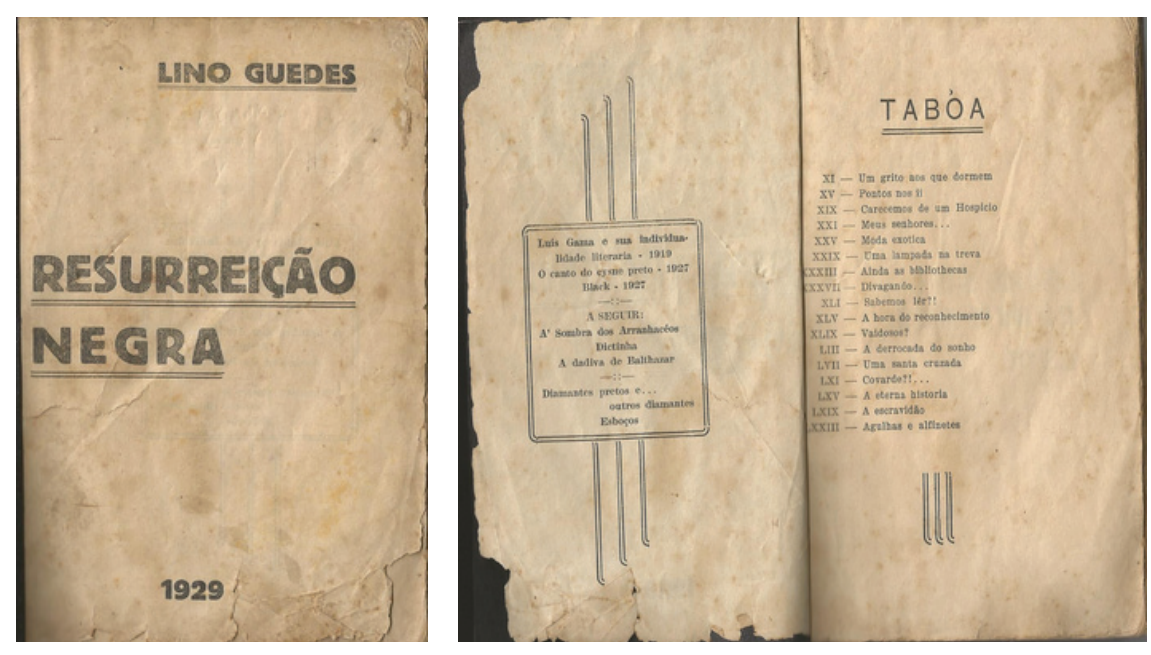

Fonte: Acervo Particular Mário A. M. da Silva.

Infelizmente não tive acesso à capa de Ressurreição, pois o volume encontrado foi encadernado. 0 livro é a reunião de artigos escritos desde 1924, com discursos em atos públicos. Os esforços para erguer a herma de Luiz Gama se estenderam por mais de um ano, visando a memória pública do protagonismo negro contra a escravidão, num local de extrema importância - a herma está no Largo do Arouche, defronte ao prédio da Academia Paulista de Letras. Quando finalmente foi inaugurado o monumento, alguns jornais conferiram atenção especial ao fato (Cuti e Leite, 1992: 83-88). Vale ressaltar que isso ocorreu também pela grande presença de autoridades públicas, bem como pelas homenagens conjugadas a negros e brancos pela Abolição e pela República:

Deu-se hontem às 10 horas no largo do Arouche [...] a solennidade de entrega à cidade de São Paulo do monumento que a Comissão Pró-herma a Luiz Gama, por iniciativa do jornal "0 Progresso", fez erigir ao grande abolicionista. [...]

\footnotetext{
${ }^{19}$ Pró-herma de Luiz Gama. Folha da Manhã, 1ํ- de outubro de 1930, p. 10.
} 
Em primeiro lugar discursou, fazendo a entrega da herma a São Paulo, o sr. Lino Guedes, secretário geral da Comissão Pró-herma Luiz Gama. Descobriram o monumento o paranympho tenente Verissimo Glória, abolicionista e amigo pessoal de Luiz Gama e a srta. Leontina Martins Bonilha, "Miss Progresso".

Falaram a seguir, dr. Annibal Monte Serrate, do Clube 13 de Maio; Paulo Estevam dos Santos, do Grupo Carnavalesco Campos Elyseos; Alberto Orlando, pelo orgam "O Progresso" e em nome do paranympho ten. Verissimo Glória; Arlindo Veiga dos Santos, pela Frente Negra Brasileira; Benedicto Camargo, em nome dos pretos da velha guarda; Sylverio Rodrigues, pelos pretos da Bahia; e Vicente Ferreira, pela União Militar. [...] À noite, no Theatro Boa Vista, realizou-se espetáculo de gala, com as presenças do sr. interventor federal, secretários de Estado, chefe de polícia e do sr. prefeito da cidade. [...] os membros da Comissão Pró-herma a Luiz Gama, srs. Argentino Celso Wanderley, Adalberto Pires de Freitas, Benedicto Henrique Dias, João Eugenio da Costa, Horacio da Cunha, Euclides Sylverio dos Santos, Raul de Moraes e Lino Guedes.[... $]^{20}$

\section{A Figura PÚblica do POETA NEGRO}

década de 1930 foi um ponto alto da carreira de Guedes e de sua exposição como
sujeito público. ${ }^{21}$ No âmbito da Frente Negra Brasileira, através das notícias de suas reuniões, sabe-se da "marcha 'Palmares', de autoria do poeta negro Lino Guedes e música do sr. Isaltino B. Veiga do Santos, secretário geral da Frente Negra Brasileira". ${ }^{22}$

Localizei-o como declamador da Rádio Educadora Paulista: por ocasião do 13 de maio de 1932 o poeta aparece em ao menos dois momentos, com "algumas palavras", "Banzo - declamação pelo autor" e "O grito de Cham - poesia pelo autor" na chamada das $21 \mathrm{~h}$ : "Hora 13 de Maio - programma organizado pelo 'Progresso' e commemorativo da data da Abolição" (em Folha da Noite, p. 4, e Folha da Manhã, p. 11). ${ }^{23}$ Também o localizei, junto de membros do jornal negro O Progresso, como promotor de moção pelo fim da escravidão na

\footnotetext{
${ }^{20} \mathrm{Cf}$. Inaugurou-se hontem, nesta capital, a herma ao abolicionista Luiz Gama. Folha da Noite, 23 de novembro de 1931 , p. 1. Explicita-se: "Fez entrega do monumento à cidade o sr. Lino Guedes".

21 "São noivos nesta Capital, onde residem os contratantes, a senhorita Felicia Assis, filha do sr. Paulino Assis, já fallecido, e da exma. senhora dona Francisca de Assis, aqui domiciliada, e o sr. Lino Guedes, nosso companheiro de imprensa, filho do sr. José Pinto Guedes, já finado e da senhora d. Benedicta Eugenia Guedes." Cf. Chronica Social - Noivados. Folha da Manhã, 30 de agosto de 1931, p. 17.

${ }^{22}$ Cf. Frente Negra Brasileira. Folha da Noite, 06 de abril de 1932, p. 3. 0 mesmo é anunciado em 13 de Maio de 1933 neste jornal, p. 1.

${ }^{23}$ A representação dos jornalistas na Assembleia Legislativa. Folha da Manhã, 7 de agosto de 1935, p. 7. Guedes é um dos sócios signatários.
} 
Abissínia, ${ }^{24}$ poeta colaborador da Revista de São Paulo, articulista defensor das memórias de Luiz Gama e do médico negro Juliano Moreira. ${ }^{25}$

Como o reconhecido poeta negro, ele é o intelectual orgânico que vem a público tratar de assuntos que interessam à "raça". Num desses momentos, lê-se o autor com uma longa carta publicada no Diário da Noite, endereçada ao general Almerio de Almeida, comandante da 2a Região Militar, tendo como mote os 274 anos de morte de Henrique Dias:

[...] Para perpetuar a memória e a bravura do negro-soldado, mais tarde o governo imperial creou o "Batalhão dos Henriques", no qual tinham ingresso somente os pretos. [...] Se o 7 de setembro marca a independencia da nossa nacionalidade, o 13 de maio é a libertação de uma raça que, com sacrifícios inauditos, construiu o paiz, que não conta no numero de sua datas nacionaes uma que recorde a abnegação do negro escravo. Ao lado dos "Dragões", por que não se colocar o "Batalhão dos Henriques"? [...] Um povo a quem se deve esse monumento economico que é não só a lavoura de São Paulo, mas do Brasil, tem direito a compensações. [...] espero ouvir de v. excia. a voz de commando que ecoará de quebrada em quebrada, por toda a cabralina terra, ordenando justiça aos filhos pretos de Isabel [...] Agradeço, como filho de militar que sou, perfilado, em continencia: - Obrigado, meu general! (a) Lino Guedes. ${ }^{26}$

Não fica claro se havia uma demanda coletiva que embasasse a carta de Guedes (Kraay, 2012: 135-136 ). Compara-se a necessidade de criação de um batalhão de honra aos negros com a mesma medida que, em 1927, levou o Senado Federal à criação dos Dragões da Independência para desfilar pela comemoração da independência brasileira. Além disso, os termos "negro", "preto", "raça", cambiáveis no texto, não sinalizam uma hierarquia, mas sim uma resultante para a questão negra. A contribuição dos braços negros à lavoura, à armada e à economia brasileira não poderia ser esquecida pela memória nacional na terceira década do século XX. E há "os filhos pretos de Isabel" numa imagem forte associada à Princesa Imperial e seu gesto na libertação dos escravizados (Daibert Jr, 2004). E, por fim, a menção à sua filiação com ascendência militar: refere-se ao pai biológico ou ao "coronel", com patente que tanto pode ser carreira ou distinção de chefia política da antiga Guarda Nacional, criada em 1831.

Guedes efetua algo de excepcional ao publicar em livros seus poemas e fazer-se conhecido de leitores além da esfera endógena de associações e periódicos negros. Como fez

\footnotetext{
${ }^{24}$ A extinção da escravidão na Abissínia: apoiando essa idéia, os pretos de São Paulo acabam de enviar moção de simpatia a S.M. Haile Selaissie. Correio de S. Paulo, 18 de junho de 1932, p. 1.

25 "Oh! Não façam isso!" e "Juliano Moreira, negro retinto". Correio de S. Paulo, 1 e 24 de maio de 1933, respectivamente. As colaborações para a revista são indicadas no mesmo jornal ao longo do ano de 1933.

${ }^{26}$ Há 274 anos morria, na data de hoje, o famoso Henrique Dias. Diário da Noite, 31 de agosto de 1935, p. 2.
} 
isso? A presença na revisão dos jornais dos Diários Associados e o apoio das associações negras são pistas, mas não satisfazem plenamente a questão de como acionou redes de publicização.

Seu volume de poemas Urucungo sai em 1936, pela editora gráfica Cruzeiro do Sul, e recebe menção no Correio Paulistano, assinada por autor com pseudônimo de imperador inca, "Atahualpa", que qualifica tanto Guedes como os negros em termos condescendentes: poeta indulgente, quase ingênuo, que representaria uma "raça" com as mesmas características. Ocorre contraponto com a linha de cor estadunidense, onde o preconceito e discriminações explícitas teriam sido melhores para os negros se organizarem autonomamente, em comparação com bondade civilizada à brasileira, que, apesar de melhor que a crueldade dos Estados Unidos, não teria sido capaz de oferecer o mesmo salto para o futuro:

O outro livro [...] é de um poeta negro, Lino Guedes. "Urucungo" é o título da obra, toda em versos e bons versos. 0 poeta é dulçoroso, melachollico, sentimental e melodioso. [...] Lino Guedes é preto, faz parte dessa raça forte que, no Brasil, se esbate de decadencia em decadencia. ${ }^{27}$

\section{Imagem 4: Urucungo, 1936, Estabelecimento Gráfico Cruzeiro do Sul. Início da Coleção Hendi, anunciando próximo livro.}
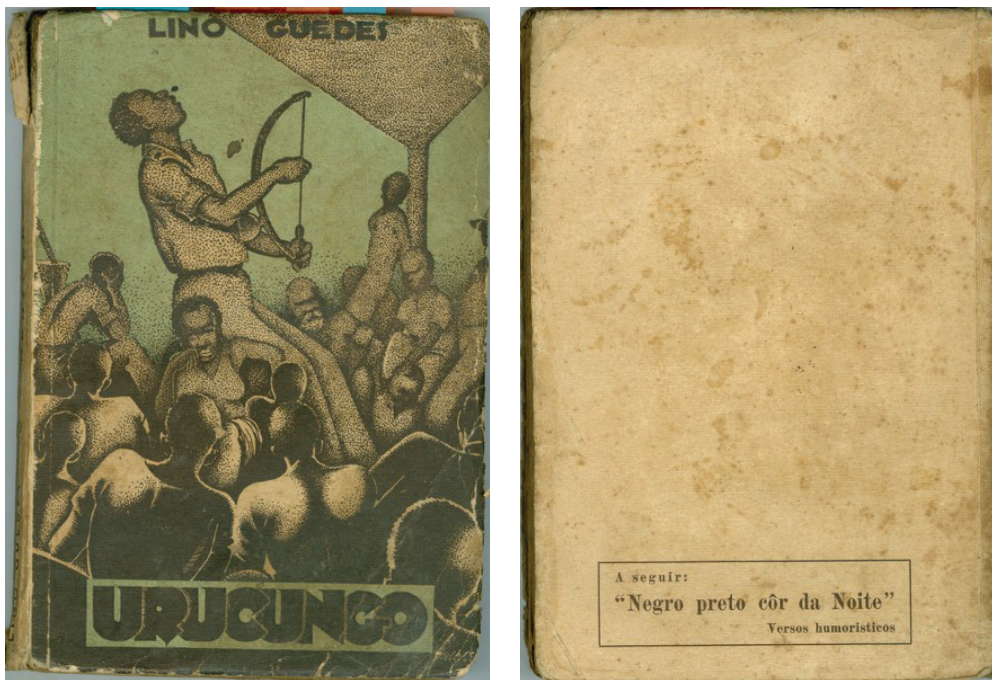

Fonte: Acervo Particular Mário A. M. da Silva

\footnotetext{
${ }^{27}$ De Relance. Correio Paulistano, 1 de abril de 1936, p. 5.
} 
Homônimo do livro de 1932 de Raul Bopp, o Urucungo de Guedes não faz qualquer menção ao poeta modernista. De versos livres e com a intenção de fazer "um livro urucungo, só de gemido negro [...]", que fosse "parte: África: pré-histórico, sexual místico" e parte "cativeiro, troços da lavoura" (Bopp, 1932: 8 apud Oliveira, 2014: 68), Bopp não tencionava tratar do negro após 1888. Retomado o título e ressignificada a palavra para o poeta Lino Guedes, quatro anos depois, misturando memórias lamuriosas - embaladas pelo urucungo (instrumento musical) tocado por Pai João -, diversos poemas tratam do tempo da escravidão, cheios de dor e sentimentos; mas também pela voz lírica do poeta que observa o presente como em "O Poema das Mãos Enegrecidas", do qual se reproduzem excertos: "O neto de Pae João/ logo após a Abolição/ Não pensou em se vingar/ De quem tanto o escravisára/ [...] E o neto de Pae João/ Soffreu a desillusão/ de ficar por toda a vida/ - Como a pedir uma esmola/ para a mísera sacola, -/ Com sua mão destendida" (Guedes, 1936: 59-60). A capa é assinada pelo caricaturista Rosasco ${ }^{28}$ e inicia a "Coleção Hendi", nome de sua filha.

Urucungo também figura em maio de 1936 entre os livros recebidos pelo comentarista de publicações Jayme de Barros, do Diário da Noite, ao lado de Casa Grande \& Senzala, de Gilberto Freyre. ${ }^{29}$ Alguns dias depois, no mesmo jornal, lê-se na seção "Livros Novos" uma nota exclusiva sobre o mesmo livro de Guedes:

0 sr. Lino Guedes consagrou-se por um gênero de poesia que se caracteriza por uma simplicidade absoluta da forma, das idéias, dos sentimentos. Mais dos sentimentos, como convém à poesia, do que das idéias. "Urucungo" possui algumas poesias scriptas com o mesmo rhytmo dolente das músicas, das danças negras. [...] 0 sr. Lino Guedes é [...] um poeta sem complicações literárias - espontâneo como poucos. Por isso mesmo se lê com satisfação o seu livro. ${ }^{30}$

Necessário observar, novamente, o movimento pendular da figura do autor, entre 0 mundo dos brancos e o mundo dos negros. No primeiro, sua imagem figura como uma expressão de ingenuidade e ausência de luta revanchista pelo passado; no segundo, é sempre interessante assinalar seu papel em associações e atos, como num desses momentos, ao se tratar da União Nacional dos Homens de Cor.

Na sede da União Nacional dos Homens de Côr, à rua São Bento, 12, onde está installada a comissão central do Hospital Henrique Dias, realizou-se no dia 3 do corrente, a assembleia

\footnotetext{
28 "José Guido Rosasco (1900). Desenhista e caricaturista. Estudou no Liceu de Artes e Ofícios de São Paulo e, no início da década de 1920, colaborou com caricaturas para vários periódicos: 'Diário da Noite', '0 Combate', 'A Gazeta', além de vinhetas e desenhos de humor para 'A Cigarra', 'Revista de São Paulo' e 'A vida moderna'. " Cf. Piazza (2003: 320).

${ }^{29}$ Jayme de Barros, Espelho dos livros - livros recebidos. Diário da Noite, 11 de maio de 1936, p. 2.

${ }^{30}$ Livros Novos. Diário da Noite, 29 de maio de 1936, p. 5.
} 
ordinária dessa entidade, na qual foram eleitos para dirigir os destinos sociaes no período que vão até 4 de agosto de 1937, os seguintes srs.: presidente dr. Manuel dos Passos [...] Orador official, o poeta negro Lino Guedes. [...] $]^{31}$

Neste momento, sua participação na Frente Negra Brasileira (1931-1937) é recordada por um antigo membro, Francisco Lucrécio: "Nos cursos, os professores davam aulas gratuitamente. [...] Existiam diversos professores: o Raul Amaral, o Lino Guedes, que era jornalista, Salatiel Campos, que também era jornalista. [...] A escola foi importante, principalmente quando a Frente Negra afundou na questão política. Então, precisaria que o negro se alfabetizasse para tirar o seu título de eleitor." (Barbosa, 1998: 42).

\section{Imagem 5: Negro Preto Cor da Noite, 1937. Capa de Rosasco. Estabelecimento Gráfico Cruzeiro do Sul. Coleção Hendi.}
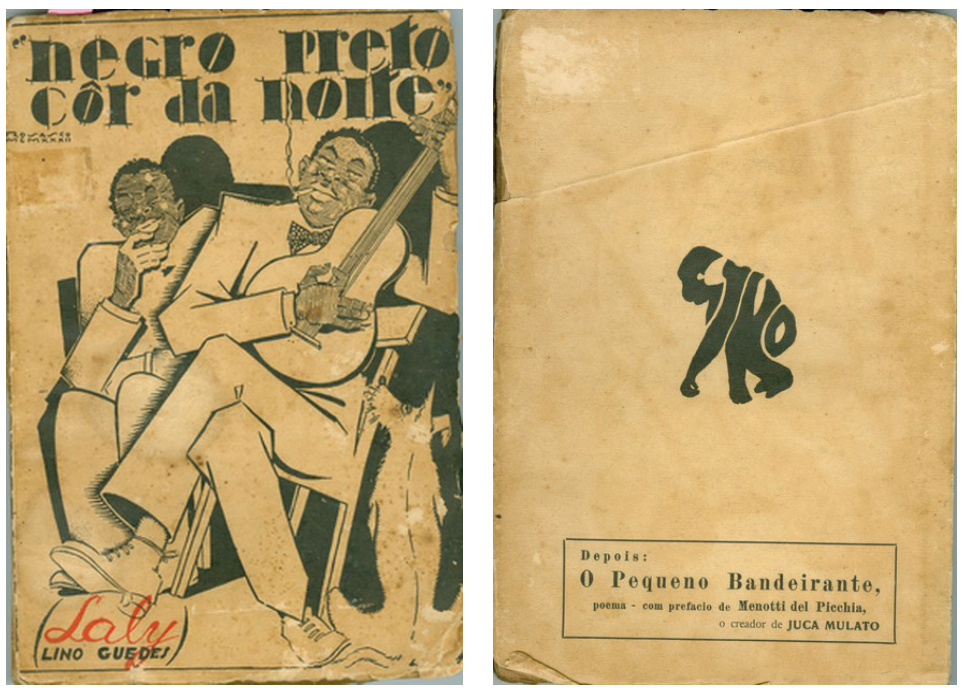

Fonte: Acervo Particular Mário A. M. da Silva.

Publicado em 1937, Negro preto cor da noite recebe uma pequena menção no Correio Paulistano, novamente de Atahualpa, num texto que se dedica a discutir a presença estatística do negro na sociedade brasileira desde o início do tráfico de escravos:

[...] o preto é uma raça forte e sadia, que já dominou o mundo [...] No Brasil, ella está abandonada, entregue à sua própria sorte e em vias de degenerescência. [...] Ainda agora tive uma prova da

\footnotetext{
${ }^{31}$ Na União Nacional dos Homens de Cor. Folha da Manhã, 5 de agosto de 1936, p. 5. Sobre a União Nacional dos Homens de Cor e a proposta do Hospital Henrique Dias, ver Domingues (2004: 355).
} 
affectividade dessa gente, recebendo um bello livro de versos, "Negro preto côr da noite", desse melodioso e sentimental poeta côr de carvão, o intelligente Lino Guedes, mais conhecido por Laly. É um Campoamor ou João de Deus, de origem africana, espontaneo, correntio, lyrico, sincero. [...] $]^{32}$

A capa é novamente assinada por Rosasco. Negro preto, cor da noite é também um dos versos famosos de Guedes, presente neste livro, que expressa uma crítica ao comportamento mundano negro. Isso aparece em "Dedicatória": "Oh, negrada, destorcida!/ que não quer não, outra vida/ melhor que esta de chalaça/ por entre fumo e cachaç a[...] este livrinho - um entulho/ à sua malemollencia,/ o qual falará da dor/ desta infeliz gente negra,/ gente daqui da pontinha/ desgraçada gente minha/ A gente do meu amor!" e em "Novo Rumo": "Negro preto côr da noite, / nunca te esqueças do açoite/ que cruciou tua raça./ Em nome della somente/ Faze com que nossa gente/ um dia gente se faça!/ Negro preto, negro preto/ sê tu um homem direito/ como um cordel posto a prumo!/ É só do teu proceder/ que, por certo, ha de nascer/ a estrella do novo rumo!" (Guedes, 1937, s/p).

Na mesma seção do jornal, meses mais tarde, é atestada uma produção continuada de poemas de Lino Guedes através dos comentários a O Pequeno Bandeirante e Mestre Domingos:

[...] Accuso o recebimento de mais dois livros desse operoso poeta côr da noite, que é Lino Guedes, tão espontâneo e sincero nas suas versificações. "0 pequeno bandeirante" e "Mestre Domingos" são as novas producções desse poeta correntio e extremamente sentimental. 0 primeiro é um poemeto inspirado em certos episodios da nossa revolução de 32. No segundo, exalta os benefícios da instrucção e em ambos desnuda todo o seu carinho para os seus companheiros de raça, sem ódio contra os brancos. [... $]^{33}$

O Pequeno Bandeirante insere o negro no conflito iniciado em São Paulo com o poder central em 1932. 0 personagem homônimo, da primeira parte do livro, é uma criança que quer lutar por São Paulo. Prefaciada pelo poeta Menotti del Picchia e ambientada em Campinas, a história narra o bombardeio da cidade em 1932, que vitimou uma criança numa estação de trem. ${ }^{34}$ Na segunda parte do livro, intitulada "Marcha dos Henriques", há aproximação da importância do batalhão negro de outrora com o destacamento da Legião Negra de São Paulo, que atuou no conflito (Domingues, 2008: 96-146; Faustino, 2011). A capa e as ilustrações são

\footnotetext{
32 De Relance. Correio Paulistano, 9 de janeiro de 1937, p. 5.0 espanhol Ramon de Campoamor y Campoosorio (18171901) e o português João de Deus Nogueira Ramos (1830-1896), ambos poetas caracterizados por seu lirismo romântico. ${ }^{33}$ De Relance. Correio Paulistano, 4 de maio de 1937, p. 5.

34 Um episódio desta natureza ocorreu em 18 de setembro de 1932, vitimando o escoteiro Aldo Chioratto. Cf. http://jornal. puc-campinas.edu.br/livro-resgata-memoria-perdida-de-campinas/ e https://campinasnostalgica.wordpress.com/2014/03/18/ bombardeio-em-campinas-1932/ Acessados em 23 de abril de 2017.
} 
assinadas por Messias, que fará outros trabalhos gráficos para Guedes. 0 artista é Manoel Messias de Mello (1904-1994), ilustrador e quadrinista alagoano que trabalhou na imprensa paulista - especialmente nos jornais $A$ Gazeta e A Gazeta Esportiva, tendo colaborado com ilustrações para o conflito de 1932. Messias também era irmão do jornalista Judas Isgorogota (pseudônimo de Agnelo Rodrigues de Mello), prefaciador de O Canto do Cysne Preto.

Imagem 6: O Pequeno Bandeirante, 1937. Coleção Hendi. Estabelecimento Gráfico Cruzeiro do Sul. Ilustração e capa de Messias.
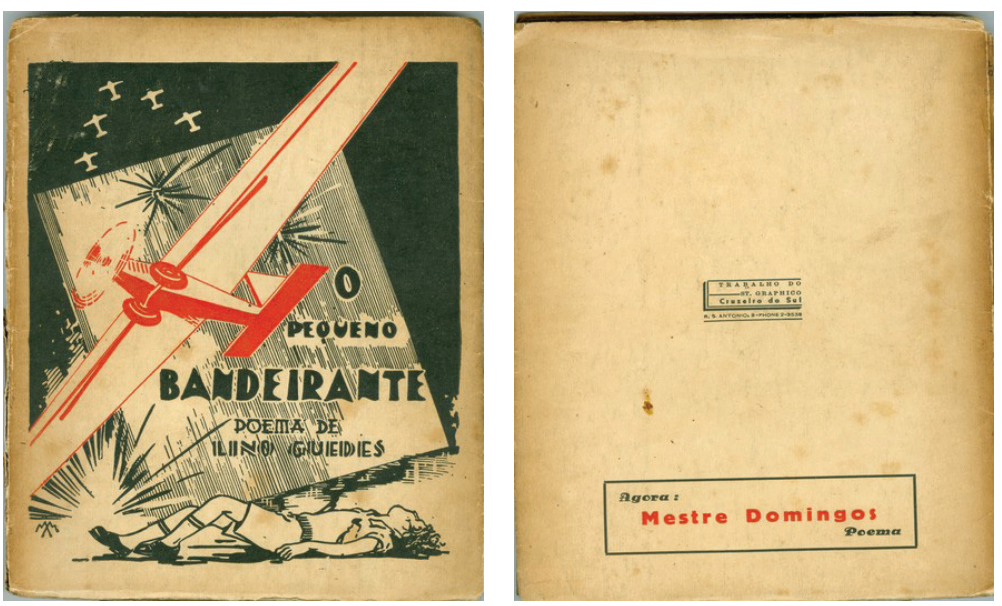

Fonte: Acervo Particular Mário A. M. da Silva

Imagem 7: Mestre Domingos, 1937. Desenho de Rosasco. Typograhia Cruzeiro do Sul. Coleção Hendi.
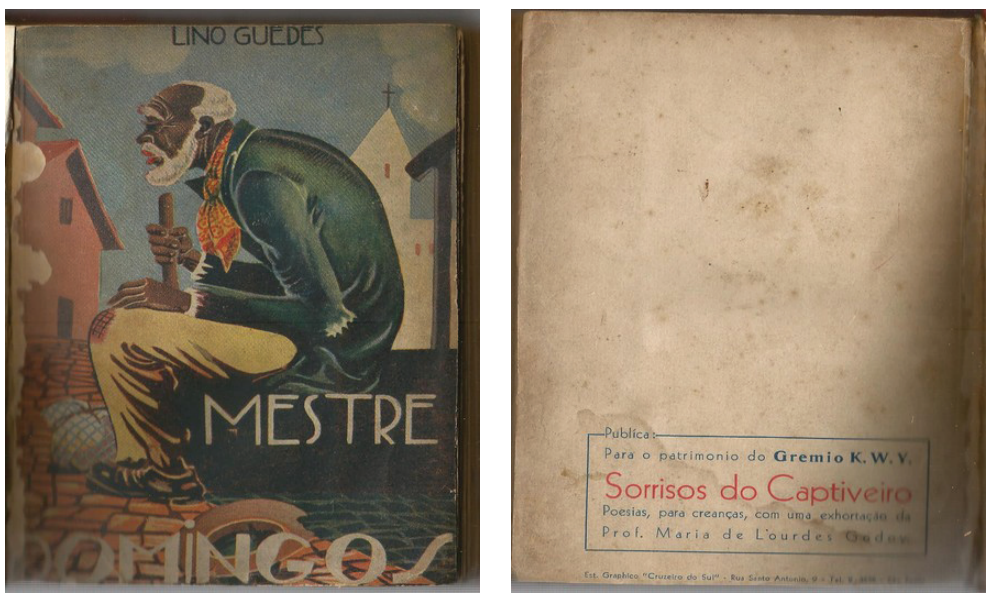

Fonte: Acervo Particular Mário A. M. da Silva 
Mestre Domingos conta a história de um escravizado cuja função era levar os filhos de seu senhor à escola. Por ficar do lado de fora da sala de aula, ele aprendia ouvindo as lições e repassava-as posteriormente aos outros escravizados na senzala. Domingos compra a sua liberdade e a de Damiana, com o auxílio do rábula Luiz Gama. Ela é uma mulher mais jovem, que se torna sinônimo de desventura para o mestre. Misturam-se duas narrativas de liberdade: a ação coletiva pela liberdade (compra de alforria por escravizados) com um sentido público positivo. E o sentido privado, pelos infortúnios amorosos de Domingos e Damiana.

Em 1937, tanto a comemoração ao 90 aniversário de Castro Alves, para o qual a Frente Negra Brasileira é convidada a participar e em que Guedes figura como orador com seus versos, ${ }^{35}$ como a homenagem da Frente Negra Brasileira à cantora lírica negra e estadunidense Marian Anderson, onde novamente Guedes será um orador, são destaques. Sobre as notícias acerca da homenagem a Anderson, vale reproduzir os seguintes excertos:

A presença em São Paulo, de passagem para Buenos Aires, da cantora negra norte-americana Marian Anderson, revolucionou os nossos meios artísticos. [...] A Frente Negra Brasileira, expressão de valor dos nossos patrícios de côr, prestou significativa homenagem à illustre cantora visitante [...] Sabbado à tarde, Marian Anderson, acompanhada de seu empresário, o sr. Franz Worwitz, visitou a sede central da "Frente Negra Brasileira" [...] sendo saudada pelo presidente, sr. Justiniano Costa, servindo de traductor o dr. [Arlindo] Veiga dos Santos. Fizeram-se ouvir, em números musicaes, a menina Dirce Marcondes, o cantor Mario Santiago, Oswaldo Martins, Rubens Costa e Celina Vieira, a duas vozes, e o poeta negro Lino Guedes recitou em francez "Curiosité". [Marian Anderson recebeu um estojo em cartão de prata com a seguinte dedicatória]: "À Marian Anderson, homenagem dos negros do Brasil. Frente Negra Brasileira. São Paulo. Junho - 1937". [...] Profundamente emocionada, a homenageada respondeu [...] que em toda a sua excursão artística pelo mundo, era a segunda vez que recebia homenagens assim, de seus irmãos de raça, sendo que a primeira fora em Paris. [...] A sua permanencia no Brasil era curta, mas esperava e tinha certeza de retornar, com mais vagar a São Paulo, e viver mais tempo entre os seus irmãos de raça, cujo valor intellectual ela já ouvira falar em sua terra. [... $]^{36}$

\footnotetext{
${ }^{35}$ Homenageando a memória de Castro Alves. Folha da Manhã, 16 de março de 1937, p. 1. A homenagem foi organizada e composta em 14 de março no Theatro Municipal de São Paulo.

${ }^{36}$ Cf. Os negros de S. Paulo homenagearam Marian Anderson. Correio Paulistano, 23 de junho de 1937, p. 11. A mesma homenagem é noticiada pelo Diário da Noite, com o título "Marian Anderson, a extraordinária cantora negra foi homenageada pela Frente Negra" (23 de junho de 1937, p. 5). Marian Anderson (1897-1993) foi uma das primeiras cantoras líricas negras estadunidenses e uma das mais importantes do século XX, estando em atividade entre 1925 e 1965, bem como ativista da luta antidiscriminação racial.
} 
Entre julho e agosto de 1937 noticia-se que "As associações e elementos negros de São Paulo, bem como amigos e admiradores do poeta negro Lino Guedes, nosso collega de imprensa, projectam-Ihe uma homenagem [...]". ${ }^{37}$ Entre os organizadores, estavam Francisco Lucrécio, da Frente Negra Brasileira, bem como o escritor Oswald de Andrade. 0 evento era por sua produtiva e constante atividade literária e, além de um almoço, haveria a reedição de seus livros. Em 1938 o Cinquentenário da Abolição em São Paulo, organizado por Mário de Andrade, foi objeto de debates promovidos pelo Departamento de Cultura (sob direção do poeta modernista até 1937). 0 projeto de Andrade previa a participação de associações e intelectuais negros da cidade, Lino Guedes incluso:

[...] As associações negras, por sua vez, farão realizar várias conferências que estarão a cargo dos intellectuaes Arlindo Veiga dos Santos, Lino Guedes, Guaraná Sant'Anna, Fernando Goes, Raul Amaral, Silverio Lima e Sebastião Scheffini. Essas palestras serão no Departamento de Cultura e no Palácio Trocadero. ${ }^{38}$

A notícia do Correio Paulistano (10 de maio de 1938, p. 7) anuncia que Lino Guedes e Fernando Goes pronunciaram suas conferências sobre "a Abolição e problemas correlatos" no Theatro Municipal. Já no Trocadero, Veiga dos Santos tratou de "Uma doutrina para o negro"; Francisco Lucrécio falou sobre "A liberdade e o negro"; Raul do Amaral fez uma "Synthese da vida de Luiz Gama"; Silverio de Lima tratou da "Influência do negro na formação econômica e política do Brasil"; enquanto Antonio Pereira dissertou sobre o tema "Uma raça infeliz".

No dia 12 de maio, o Correio Paulistano (p. 17) noticia que Guedes está em Campinas, no encerramento do Congresso Afro-Campineiro, debatendo o tema "Existe ou não o preconceito de cor?". O Congresso foi organizado por Abdias do Nascimento, Aguinaldo Camargo, Geraldo Campos entre outros (Nucci, 2012). Além da participação em Campinas e São Paulo, Guedes iria a Bragança Paulista, segundo a Folha da Manhã, de 14 de abril de 1938 (p. 13), tratar do mesmo tema na Igreja do Rosário. E é o ano em que ele publica mais um livro: Vigília de Pae João, dedicado ao cinquentenário de 1888.

\footnotetext{
${ }^{37} \mathrm{Cf}$. Homenagens. Correio Paulistano, 16 de julho de 1937, p. 4.0 mesmo anúncio aparece nos dias 18, 20, 22, 23, 24, 28, 30 e 31 de julho, bem como 18 e 19 de agosto de 1937. Noticiado na Folha da Manhã, em 14 e 17 de agosto de 1937, sendo que nesta última, é frisado que a homenagem será ao Sr. Negro Lino Guedes, bem como o nome de alguns dos adesistas ao almoço.

${ }^{38}$ Cincoentenário da Abolição. Correio Paulistano, 23 de abril de 1938, p. 4. A mesma matéria no dia 26 e 28 de abril de 1938.
} 


\section{Imagem 8: Vigília de Pae João, 1938. Coleção Hendi. Typograhia Cruzeiro do Sul. Capa, desenhos e selo interno de Messias.}
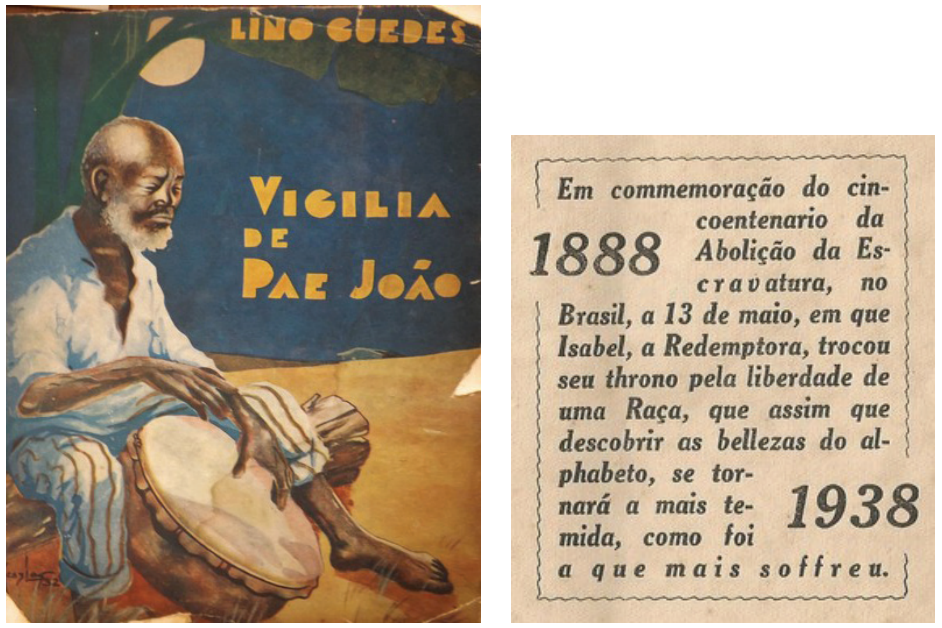

Fonte: Acervos Particulares de Oswaldo de Camargo e Mário A. M. da Silva.

Vigília de Pae João é a história de um plano de fuga arquitetado por escravizados numa fazenda, narrado em poema dramático. Pai João, por ser o mais velho e mais experiente (foi um fugitivo na juventude), ensina seus pares de senzala como planejar a escapada, misturando artifícios místicos com um roteiro de memória ao Quilombo do Jabaquara (que levaria a Santos e à liberdade efetiva). Pai João exorta seus companheiros a terem sucesso onde ele falhou, uma vez que voltou a ser escravizado. Para tanto, ele se sacrifica no plano, em prol dos fugitivos mais jovens.

Em 1939, encontra-se Lino Guedes ativo na entidade de classe dos jornalistas, ${ }^{39}$ participando ainda de um ciclo de debates sobre a profissão, no qual fala a partir de sua posição, de revisor. ${ }^{40}$ Suas atividades como escritor terão um intervalo longo.

\section{Movimentos de DefesA-ATAQUe E SiLÊNCiO}

$\mathrm{R}$ oger Bastide foi pioneiro nos estudos sobre literatura negra brasileira e imprensa negra paulista com o artigo de 1941 tratando da poesia de Gonçalves Crespo e Lino Guedes,

\footnotetext{
${ }^{39}$ Associação Paulista de Imprensa. O Estado de São Paulo, 6 de abril de 1939, p. 10; Realizam-se hoje as eleições da Associação Paulista de Imprensa. Folha da Manhã, 15 de abril de 1939, p. 1.

40 "Continuando a série de Palestras Quinzenaes que deliberou levar a efeito, o grupo de revisores ligados à APISP promoverá hoje, às 16 horas, mais uma conferência, que está a cargo do sr. Lino Guedes, revisor do 'Diario de S. Paulo'. 0 thema do orador desta tarde está subordinado ao título 'Coisas do revisor'". Cf. Associação dos Profissionaes de Imprensa de São Paulo. Folha da Manhã, 29 de outubro de 1939, p. 8.
} 
onde ele cunha a ideia de um puritanismo negro como traço poético expresso por Guedes (Bastide, 1941: 4-5; 1973: 107-109). Ele entendeu o puritanismo como um regramento comportamental que tem a ver com a constituição da sociedade burguesa, com valores assimilados pelo negro. Em que Guedes narra o passado da escravidão, tendo o mote da memória e da exposição de feitos de resistência e bravura como pontos fortes, aliado a um estado de melancolia de seus personagens e uma observação ao comportamento mundano. 0 passado vigia os atos daquele presente negro, condicionando-o a uma vida reta e exemplar, exigindo-se respeito ao negro que se fizesse respeitar (que não fumasse, bebesse ou vivesse em cordões e bailes; que casasse e fizesse esforços para comprar casa, organizando a família negra saindo de porões e cortiços; que estudasse e elevasse o nome dos negros).

Creio ser necessário repensar essa perspectiva. No tempo da escrita mais profícua de Guedes e de atuação de associações como a Frente Negra Brasileira (1931-1937), a cidade de São Paulo foi chocada por casos de crimes atribuídos a negros que foram retratados como monstros, alvos de críticas morais, de medições antropomórficas e debates legais, metonímicos de todo o grupo social. Refiro-me a "O caso do Preto Amaral" (1927) e a "O crime do restaurante chinês" (1938) (Fausto, 2009)], que foram exemplares de toda sorte de preconceito racial e discriminações cotidianas e científicas com relação à população negra (Tiede, 2006; Campos, 2003). Guedes, com seus poemas, e seus pares, com o ativismo, soam como um movimento de defesa-ataque: distinguir-se desses e outros estereótipos, defendendo seu grupo e apontando um caminho de retidão, pela poesia e ação política, para atacar o racismo vigente.

A exposição de Guedes ao longo da década de 1940 será menor, assim como a publicação de seus poemas em livros. Tem-se notas espaçadas de sua participação, em 1942, como chefe de revisão do Diário de São Paulo, em homenagem a Benedito Florencio, vulgo "Machadinho", jornalista negro de Campinas, com quem possuía laços de amizade; ${ }^{41}$ ou, ainda, um pedido de registro como jornalista (Folha da Manhã, 21 de março de 1943, p.13); em 22 de setembro de 1944, pronunciou com Gervásio de Moraes (seu antigo colega de Getulino), uma conferência no Teatro Municipal de Campinas sobre "O passado do negro no Brasil" (Folha da Manhã, p. 12); foi colaborador da revista negra Senzala (ano I, 1946) com o poema "Maracatú"; em 1948 encontra-se entre os escritores inscritos para o I Congresso Paulista de Poesia, organizado por Antonio Candido, Sergio Milliet e outros. ${ }^{42}$ Além disso, no mesmo ano, sabe-se que era repórter credenciado junto ao Palácio do Governo de São Paulo, pelo fato de haver perdido sua carteira no Rio de Janeiro (Diário da Noite, 17 de fevereiro de 1948, p. 3).

\footnotetext{
${ }^{41}$ Associação Campineira de Imprensa. Correio Paulistano, 7 de julho de 1942, p. 5.

${ }^{42}$ I Congresso Paulista de Poesia. Folha da Manhã, 22 de fevereiro de 1948, p. 2.
} 
Seu último livro foi Suncristo, reunião de diversos poemas, em 112 páginas, que mesclam temas já enfrentados por ele - a escravidão, o passado, a melancolia - com poemas de temática mais mística.

\section{Imagem 9: Suncristo, 1950. Coleção Hendi. Capa de Messias. Empresa Gráfica da "Revista dos Tribunais".}
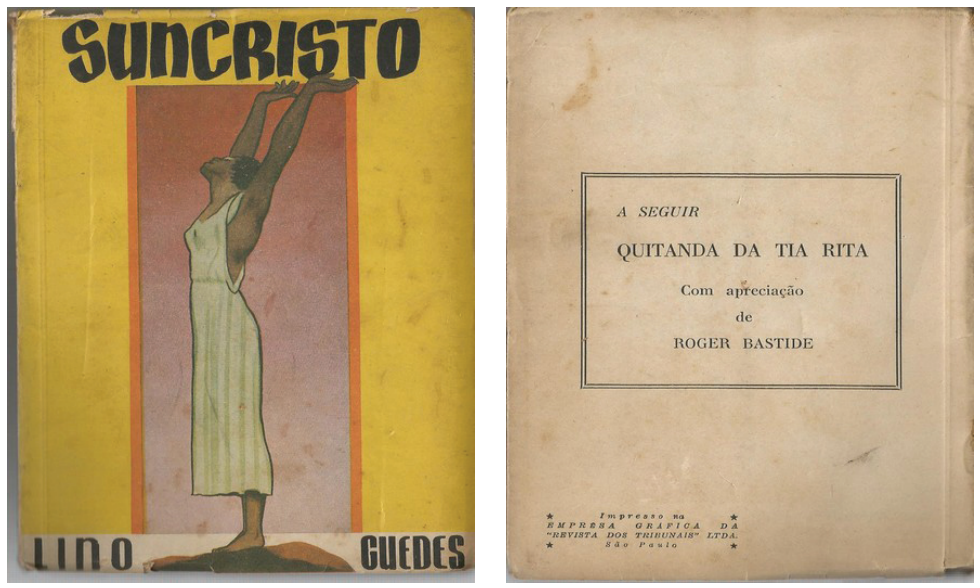

Fonte: Acervo Particular Mário A. M. da Silva. Último livro, anunciando um próximo, com prefácio de Bastide.

Considerando o documento de pedido de aposentadoria por invalidez apresentado neste artigo, expedido em dezembro de 1950, pode-se deduzir que Guedes padecia havia algum tempo de alguma doença, o que inviabilizava suas atividades públicas, como foi apontado pelo prefaciador de seu último livro, o filólogo da USP Silveira Bueno, na Folha da Manhã. ${ }^{43}$ Ele faleceu em 3 de março de 1951 por insuficiência cardíaca e foi sepultado no cemitério do Araçá em São Paulo. ${ }^{44}$ Não recebeu homenagens subsequentes do meio literário e jornalístico ou das associações negras, aparentemente, mas anos depois seu nome foi dado a uma rua em São Paulo. ${ }^{45}$

\footnotetext{
${ }^{43}$ Prof. Silveira Bueno, Questões de Português, Folha da Manhã, 27 de março de 1951, p. 4.

${ }^{44}$ Informação obtida na certidão de óbito de Lino Guedes, lavrada no Cartório de Registro Civil do 21 o Subdistrito da Saúde. Acervo da Família. Fonte: J.R. Queiroz e Marciano Ventura.

${ }^{45} \mathrm{Cf}$. Biblioteca da Câmara Municipal de São Paulo. Disponível em http://camaramunicipalsp.qaplaweb.com.br/iah/fulltext/ leis/L4891.pdf Acessado em 26/04/2017. A rua Lino Guedes está submetida hoje ao distrito Cursino, segundo a Prefeitura de São Paulo. Note-se mais uma variação do ano de nascimento e a ausência de menção ao fato de se tratar de um raro poeta negro no começo do século XX. Guedes também nomeia endereços nas cidades de Socorro e Campinas, importantes em sua trajetória inicial.
} 
Dada a lacuna de conhecimento sobre Guedes, a pesquisa de fontes nos arquivos revelou-se fundamental para mapear a circulação do escritor, tanto no meio negro como em espaços distintos deste, nos jornais convencionais ou entre intelectuais não negros. Através dele flagra-se um processo de protagonismo do negro na sociedade paulista após a Abolição. Trata-se de um percurso sinuoso, marcado por imagens preconceituosas, com as quais esse sujeito tem de se haver. E um recurso de Lino Guedes foi unir a história social do negro, presente e passada, que ele conhecia, com sua expressão poética, publicando-a às suas expensas. A análise dos jornais foi apenas uma etapa inicial. Mas, sem ela, não seria possível enquadrar o escritor negro Lino Guedes num desenho maior, qual seja: o do esforço coletivo de intelectuais e ativistas negros para serem protagonistas da sua história nas primeiras décadas do século XX, bem como das condições sociais para aquela produção.

\section{REFERÊNCIAS BIBLIOGRÁFICAS}

BARBOSA, Márcio (org.). Frente Negra Brasileira: depoimentos. São Paulo: Quilombhoje, 1998.

BASTIDE, Roger. Considerações sobre a poesia afro-brasileira. O Estado de São Paulo, 21 de setembro de 1941, p. 4-5.

Estudos afro-brasileiros. São Paulo: Perspectiva, 1973.

BERND, Zilá. Negritude e literatura na América Latina. Porto Alegre: Mercado Aberto, 1987.

BROOKSHAW, David. Raça \& cor na literatura brasileira. Porto Alegre: Mercado Aberto, 1983.

CAMARGO, Oswaldo de. A razão da chama: antologia de poetas negros brasileiros. São Paulo: GRD, 1986. O negro escrito. São Paulo: Secretaria Estadual de Cultura, 1987. . Lino Guedes, seu tempo e seu perfil. São Paulo: Ciclo Contínuo Editorial, 2016.

CAMPOS, Paulo F. S. "Os crimes do monstro negro": representações da degenerescência em São Paulo. Anais do XXII Simpósio Nacional de História, João Pessoa: ANPUH, 2003.

COLINA, Paulo. Axé: antologia contemporânea de poesia negra brasileira, São Paulo: Global Editora, 1982.

CUTI e LEITE, José Correia. ...E disse o velho militante José Correia Leite. São Paulo: Secretara Municipal de Cultura, 1992.

DAIBERT JÚNIOR, Robert. Isabel, a "Redentora" dos escravos: uma história da Princesa entre olhares negros e brancos (1846-1988). Bauru: Edusc, 2004.

DOMINGUES, Petrônio. Uma história não contada: negro, racismo e branqueamento em São Paulo no pós-abolição. São Paulo: Senac, 2004.

. Lino Guedes: de filho de ex-escravo a "elite de cor". Salvador: Afro-Ásia, n. 41, 2010, p. 133-166. Os Pérolas Negras: a participação do negro na Revolução Constitucionalista de 1932. A Nova Aboli-

ção. São Paulo, 2008, p. 96-146. 
DUARTE, Eduardo de Assis (org.). Literatura e afrodescendência no Brasil: antologia crítica. Os Precursores. Volume 1. Belo Horizonte: UFMG, 2011.

FAUSTINO, Oswaldo. A Legião Negra: a luta de afro-brasileiros na Revolução Constitucionalista de 1932. São Paulo: Selo Negro, 2011.

FAUSTO, Boris. O crime do restaurante chinês: carnaval, futebol e justiça na São Paulo dos anos 30. São Paulo: Companhia das Letras, 2009.

FERRARA, Miriam N. A imprensa negra paulista (1915-1963). São Paulo: FFLCH/USP, 1986.

GOMES, Heloísa Toller. Lino Guedes. In: DUARTE, Eduardo de Assis (org.). Literatura e afrodescendência no Brasil: antologia crítica. Os Precursores. Volume 1. Belo Horizonte: UFMG, 2011, p. 349-363.

GONÇALVES, José Roberto. O Getulino - um jornal de carapinha. Tese [Doutorado]. São Paulo: PUC-SP, 2012.

KRAAY, Hendrik. Os companheiros de Dom Obá: os zuavos baianos e outras companhias negras na Guerra do Paraguai. Afro-Ásia, Salvador: UFBA, vol. 46, 2012, p. 135-136.

MACIEL, Cléber. Discriminações raciais: negros em Campinas (1888-1921). Campinas: Editora da Unicamp, 1987.

MIRANDA, Rodrigo. Um caminho de suor e letras: a militância negra em Campinas e a construção de uma comunidade imaginada nas páginas do Getulino (Campinas, 1923-1926). Dissertação [Mestrado]. Campinas: IFCH/Unicamp, 2005.

NUCCI, Priscila. Abdias do Nascimento e o Congresso Afro-Campineiro de 1938. Anais do XXI Encontro Estadual de História, Anpuh, Campinas, setembro 2012.

OLIVEIRA, Luiz Henrique Silva de. Negrismo: percursos e configurações em romances brasileiros do século XX (1928-1984). Belo Horizonte: Mazza Edições, 2014.

PIAZZA, Maria de Fátima F. Os afrescos nos trópicos: Portinari e o mecenato Capanema. Tese [Doutorado]. Florianópolis: UFSC, 2003.

PINTO, Ana F. M. Imprensa negra no Brasil do século XIX. São Paulo: Selo Negro, 2010.

QUILOMBHOJE. Reflexões sobre a literatura afro-brasileira. São Paulo: Conselho de Participação e Desenvolvimento da Comunidade Negra, 1985.

SILVA, Mário Augusto Medeiros da. A descoberta do insólito: literatura negra e literatura periférica no Brasil (1960-2000). Rio de Janeiro: Aeroplano, 2013.

SIQUEIRA, Lucília. Bens e costumes da Mantiqueira: o município de Socorro no prelúdio da cafeicultura paulista (1840-1895). São Paulo: CLA/Fapesp, 2005.

TIEDE, Lívia M. Sob suspeita: negros, pretos e homens de cor em São Paulo no início do século XX. Dissertação [Mestrado]. Campinas: IFCH, 2006.

VON SIMSON, Olga. Carnaval em branco e negro (1914-1988). Campinas: Ed. Unicamp, 2007.

\section{Periódicos}

Acervos da Hemeroteca Digital da Biblioteca Nacional; O Estado de São Paulo; Folha de São Paulo. 